\title{
Methanol Electro-Oxidation on Carbon-Supported PtRu Nanowires
}

\author{
Gláucia R. 0. Almeida ${ }^{1,2}$, Franz E. López-Suárez ${ }^{3, *}$, Lays S. R. Silva ${ }^{1,2}$, Gabriel F. Pereira ${ }^{1,2}$, \\ Agustin Bueno-López ${ }^{4}$, Katlin I. B. Eguiluz ${ }^{1,2}$, and Giancarlo R. Salazar-Banda ${ }^{1,2}$ \\ ${ }^{1}$ Laboratório de Eletroquímica e Nanotecnologia-LEN, Instituto de Tecnologia e Pesquisa-ITP, 49032-490, Aracaju-SE, Brazil \\ ${ }^{2}$ Programa de Pós-Graduação em Engenharia de Processos-PEP, Universidade Tiradentes-Unit, 49032-490, Aracaju, SE, Brazil \\ ${ }^{3}$ Ingeniería de Procesos y Productos Químicos y Alimentarios Group, Department of Chemical Engineering, \\ Universidad de Bogotá Jorge Tadeo Lozano, 110311, Bogota, Colombia \\ ${ }^{4}$ Materiales Carbonosos y Medio Ambiente Group, Department of Inorganic Chemistry, Faculty of Sciences, \\ University of Alicante, Ap. 99 E 03080, Alicante, Spain
}

\begin{abstract}
One of the key objectives in fuel cell technology is to improve the alcohol oxidation efficiency of Pt-based catalysts. A series of carbon-supported PtRu nanowires with different concentrations of $\mathrm{Pt}$ and $\mathrm{Ru}$ were prepared for application in methanol oxidation in acid media. The physicochemical properties and electrocatalytic activity of these catalysts during methanol oxidation are function on their structure, morphology and composition. $\mathrm{A} \mathrm{Pt}_{60} \mathrm{Ru}_{40} / \mathrm{C}$ catalyst shows the best behaviour towards methanol electro-oxidation allowing decrease the onset potential approximately $0.2 \mathrm{~V}$ respect to others PtRu/C synthesised nanowires. The structural modification of Pt by Ru and synergetic character of RuPt are main factors that could contribute to reduction of energy necessary for electro-oxidation process. The Pt and PtRu nanowires have different sizes and distribution on the substrate. The average crystallite sizes, found by XRD, are in the 4.6-5.9 nm range and the lattice parameter is between $0.3903-0.3908 \mathrm{~nm}$. Small differences with the values of the Pt/C catalyst were found. The XPS results show a prevailing presence of metallic $\mathrm{Pt}$ and $\mathrm{Ru}^{4+}$ species.
\end{abstract}

Keywords: Platinum, Ruthenium, Nanowires, Electrocatalysis, Fuel Cell.

\section{INTRODUCTION}

The production of energy is associated with economic and industrial progress. This event has increased both fossil fuel consumption and the amounts of $\mathrm{CO}_{2}, \mathrm{CO}, \mathrm{NO}_{x}, \mathrm{SO}_{x}$, hydrocarbons and particulate matter in the atmosphere. Systems with more efficient energy conversion are necessary because fossil fuel sources are decreasing and the cost of the fuels is being raised. In addition, the presence of these pollutants has negative effects on human health and increases the greenhouse effect; therefore, reducing the pollution in large urban centres is particularly necessary. ${ }^{1}$

Fuel cells have been shown to be an interesting and very promising solution to that problem providing clean electric power generation with high efficiency using non-polluting fuels, like hydrogen and renewable primary fuels on a large scale. ${ }^{1,2}$ Direct methanol fuel cells (DMFC) are one of the possible candidate power sources for future electric

*Author to whom correspondence should be addressed. vehicles. $^{3}$ The Pt electro-catalyst is the most appropriate material for alcohol oxidation; however, this system displays some problems that need solution for its practical implementation, such as high cost and the inhibition of active sites by intermediate products of the oxidation reaction. ${ }^{4}$ In the specific case of methanol oxidation, its complete anodic oxidation $\left(\mathrm{CH}_{3} \mathrm{OH}+\mathrm{H}_{2} \mathrm{O} \rightarrow \mathrm{CO}_{2}+\right.$ $\left.6 \mathrm{H}^{+}+6 e^{-}\right)$involves six electrons per methanol mole. The oxidation occurs via multi-steps with the formation of several products or reaction intermediates such as formaldehyde, formic acid and $\mathrm{CO}$, which have strong influence on catalyst performance due to active surface poisoning. ${ }^{5}$ The addition of second metal (co-catalysts) to platinum catalyst is widely considered as an alternative to diminish the Pt poisoning. ${ }^{6-10}$ The superior performance of this system for methanol oxidation with respect to pure $\mathrm{Pt}$ has been assigned to the bifunctional effect (promoted mechanism $)^{11}$ and to the electronic interaction between $\mathrm{Pt}$ and the alloyed metals (intrinsic mechanism). ${ }^{12,13}$ 
Different studies have been carried out on the effect of the addition of $\mathrm{Ru}$ in $\mathrm{Pt}-\mathrm{Ru}$ catalysts for methanol electrooxidation, establishing that the enhancement of activity and stability are related to the bifunctional mechanism of $\mathrm{Ru}$ to $\mathrm{Pt}{ }^{14-21}$ For instance, He et al. ${ }^{18}$ reported that the oxidation peak potential of methanol shifted to lower potentials while the oxidation current peak increased on the addition of $\mathrm{Ru}$ to $\mathrm{Pt}$; moreover, the activity in the electro-oxidation enhances until an optimum $\mathrm{Pt}: \mathrm{Ru}$ atomic ratio. Guo et al., ${ }^{20} \mathrm{Chu}$ and co-workers ${ }^{19}$ found that, at a ratio of $1: 1$, these catalysts exhibited the highest methanol oxidation current and a lower poisoning rate. Other variables such as structure and shape, ${ }^{15-24}$ metal size, ${ }^{23,25-27}$ preparation method and support type, ${ }^{25,27,28}$ and experimental conditions ${ }^{9,29}$ also influence the methanol electrooxidation activity of electro-catalysts. Song et al. ${ }^{30}$ demonstrated that the pore morphology of carbon supports plays a decisive role in the electro-catalytic activity of the supported Pt nanoparticles. They have shown that mesoporous carbon (with a higher electrochemical surface area) used as support for Pt nanoparticles exhibited a superior activity in fuel cell reactions in the case of liquid reactants (e.g., ethanol). This behaviour was attributed to a facilitated mass transport provided by the very good 3D interconnection of the nanospacings of their hexagonally arrayed carbon nanorods (i.e., mesopores), which lead to greater accessibility of Pt nanoparticles. In recent decades, interest in the size and morphology of Pt catalysts has been increasing, since these variables influence their catalytic activity. ${ }^{31-34}$ Conventional Pt nanoparticles with zero dimension (0-D) have a particle morphology with large number of atoms with low coordination number and defects on their surface, ${ }^{35}$ while the Pt nanostructure with a one-dimensional morphology (1-D) maintains long segments with single crystalline phase (crystallographic planes connected by grain boundaries), forming nanowire structures $^{36,37}$ with fewer atoms with low coordination number. $^{38,39}$ Different authors ${ }^{39-42}$ have established that changes in the structural and electronic properties of catalysts due to 1-D morphology can be responsible for enhanced catalytic activities towards both oxygen reduction and methanol oxidation reactions.

As the physicochemical properties and electro-catalytic activities of these catalysts during methanol oxidation depend on structure and morphology, this study investigate a series of PtRu/C nanowires with differing composition of $\mathrm{Pt}$ and $\mathrm{Ru}$ toward the methanol oxidation in acid medium by cyclic voltammetry $(\mathrm{CV})$, chronoamperometry and quasi-stationary potentiostatic polarisation. Transmission electron microscopy (TEM), X-ray powder diffraction (XRD) and X-ray photoelectron spectroscopy (XPS) were used to characterise the electro-catalysts. Moreover, the electrochemical stability of $\mathrm{PtRu} / \mathrm{C}$ nanowires was evaluated through degradation cycles by cycling the electrode potential between 0.05 and $1.30 \mathrm{~V}$ versus a reversible hydrogen electrode.

\section{EXPERIMENTAL DETAILS}

\subsection{Synthesis of the Catalysts}

The $\mathrm{Pt} / \mathrm{C}$ and $\mathrm{PtRu} / \mathrm{C}$ nanowire network catalysts were prepared by the reduction of platinum and ruthenium precursors with formic acid. ${ }^{43,44}$ However, the developed methodology used in this study does not use a surfactant assisted soft template ${ }^{43}$ and uses black carbon as support at room temperature, and it is therefore different than that for the unsupported PtRu nanowires reported by $\mathrm{Li}$ et al. ${ }^{44}$

The catalysts consisted of $40 \%$ (w/w) nominal total metal $(\mathrm{Pt}+\mathrm{Ru})$ on carbon with different nominal $\mathrm{Pt}: \mathrm{Ru}$ molar ratio: (80:20), (70:30), (60:40) and (50:50). For a typical synthesis, an appropriate amount of black carbon (N330) was dispersed in an aqueous solution of hexachloroplatinic acid $\left(\mathrm{H}_{2} \mathrm{PtCl}_{6}\right)$ and/or ruthenium chloride $\left(\mathrm{RuCl}_{3}\right)$ and formic acid $(\mathrm{HCOOH})$. The reaction was conducted for 72 hours, and after this time, the powder obtained was recovered by filtration, washed with ultrapure water and dried by evaporation at $60{ }^{\circ} \mathrm{C}$ for $30 \mathrm{~min}$. All chemicals were analytically pure and used as received (Sigma Aldrich, purity $>98 \%$ ).

The morphology and structure of the nanostructures synthesised were characterised by transmission electron microscopy (TEM, JEOL 2100 HTP JEM, operating at $200 \mathrm{kV}$ ). XRD patterns were recorded on Rigaku Ultima universal + RINT 2000/PC diffractometer equipped with $\mathrm{CuK} \alpha$ radiation source $(\lambda=0.15406 \mathrm{~nm}, 50 \mathrm{kV}$ and $100 \mathrm{~mA}$ ). The diffraction patterns were registered between $2 \theta$ angles from 15 to $90^{\circ}$, with a step of $0.02^{\circ}$ per step. XPS characterisation was carried out in a VG-Microtech Multilab 3000 electron spectrometer using $\mathrm{Mg}-\mathrm{K} \alpha(1253.6 \mathrm{eV})$ radiation source. To obtain the XPS spectra, the pressure of the analysis chamber was maintained at $5 \times 10^{-10}$ mbar. The binding energy (BE) scale was adjusted by setting the $\mathrm{C} 1 s$ transition at $284.6 \mathrm{eV}$.

Electrochemical measurements were carried out in a one-compartment glass cell using a conventional threeelectrode set up (half-cell). One 800-ppm boron-doped diamond (BDD) electrode (geometric area: $0.64 \mathrm{~cm}^{2}$ ) was used as substrate. More information regarding the setup of the assembled electrochemical system is found elsewhere. ${ }^{45}$ Substrates for the electro-catalytic materials were prepared using the procedure described by SalazarBanda et al. ${ }^{46}$ The catalysts suspension was deposited onto de BDD substrate as described in a previous report. ${ }^{47} \mathrm{Pt} / \mathrm{C}$ (10 wt\% of Pt) and PtRu/C (20 wt\% metal load with 80:20 Pt:Ru) from E-Tek commercial electro-catalysts were used as reference materials for comparison purposes.

To evaluate the behaviour of each electrocatalyst, electrochemical tests were performed in $0.5 \mathrm{M} \mathrm{H}_{2} \mathrm{SO}_{4}$ and $0.5 \mathrm{M} \mathrm{CH}_{3} \mathrm{OH}$ aqueous solutions at room temperature. The $\mathrm{CV}$ experiments were carried out between 0.0 and $0.8 \mathrm{~V}$ until stationary responses were obtained, then two voltammetric cycles were recorded between 0.05 and $1.30 \mathrm{~V}$, scanning at $20 \mathrm{mV} \mathrm{s}^{-1}$. Chronoamperometric experiments 
were performed at $0.6 \mathrm{~V}$, while anode polarisation curves were carried out between 0.2 and $0.8 \mathrm{~V}$ in the potentiostatic mode, with all data points obtained after $200 \mathrm{~s}$ of polarisation at each potential.

\section{RESULTS AND DISCUSSION}

\subsection{Physicochemical Characterisation}

Figure 1 shows the XRD patterns of $\mathrm{Pt} / \mathrm{C}$ and $\mathrm{PtRu} / \mathrm{C}$ nanowire catalysts. Diffraction peaks at $2 \theta=39.9^{\circ}, 46.2^{\circ}$, $67.9^{\circ}, 81.0^{\circ}$ and $86.1^{\circ}$ are observed in Figure 1 . These peaks are assigned to the Pt (111), (200), (220) (311) and (222) planes, respectively, which displayed the normal character of a polycrystalline Pt where the crystal structure is descripted by face centred cubic $(f c c) .{ }^{48}$ Since the carbon is used as support, all the XRD patterns show the diffraction peak at $25^{\circ}$ attributed to the (002) plane. ${ }^{49}$ No peaks regarding ruthenium species ( $\mathrm{Ru}$ or its oxides) were found for PtRu/C catalysts with 80:20, 70:30 and 60:40 molar ratios. However, their presence cannot be discounted because they may be present at a small size or even in an amorphous form. For the $\mathrm{Pt}_{50} \mathrm{Ru}_{50} / \mathrm{C}$ catalyst, the diffraction peaks shifted to higher $2 \theta$ values with respect to the corresponding peaks in the pure Pt catalyst, and peaks corresponding to metallic $\mathrm{Ru}$ were identified. The formation of Pt-Ru solid solution is considered due to the slight shift of $\mathrm{Pt}$ peaks to higher $2 \theta$ values, which is due to the atomic radius of ruthenium $(\mathrm{Ru}=$ $0.134 \mathrm{pm})$ is smaller than platinum $(\mathrm{Pt}=0.138 \mathrm{pm})$ producing a contraction of the crystal lattice. ${ }^{8,50}$ The peak broadening of the diffraction line of the Pt (220) reflection was used to calculate the average particle size according to the Debye-Scherrer equation. ${ }^{51}$ The average particle sizes found are in the 4.6-5.9 $\mathrm{nm}$ range, and the lattice parameter was between $0.3903-0.3908 \mathrm{~nm}$. Small differences in both parameters compared with those for the $\mathrm{Pt} / \mathrm{C}$ catalyst were found.

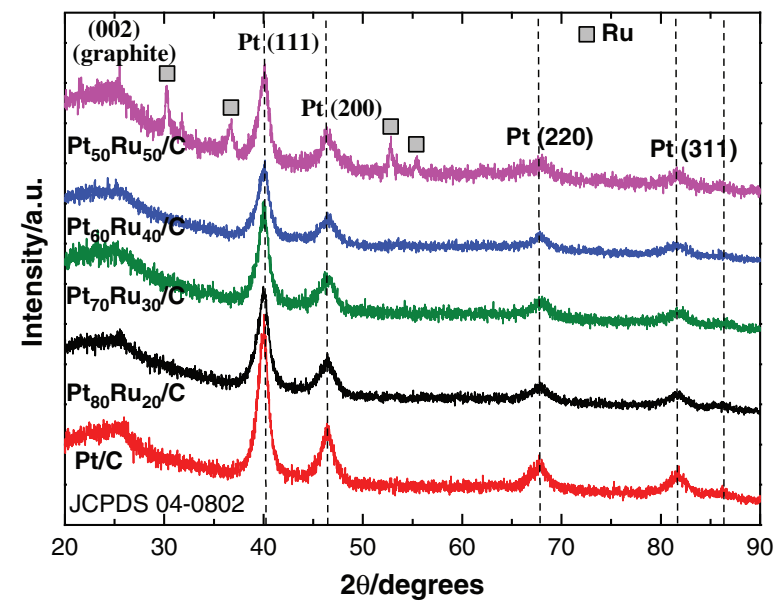

Figure 1. X-ray diffractograms taken for the developed electrocatalysts. Vertical lines indicate polycrystalline Pt peak positions.

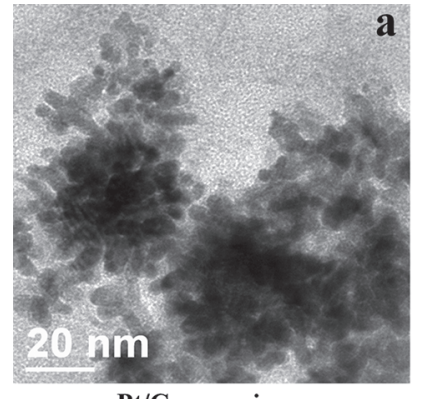

Pt/C nanowires

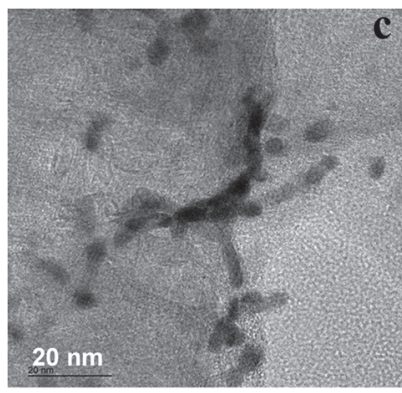

$\mathrm{Pt}_{60} \mathrm{Ru}_{40} / \mathrm{C}$ nanowires

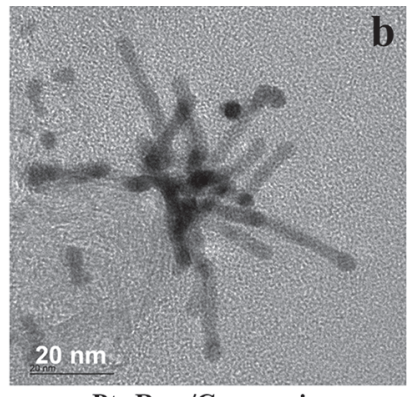

$\mathrm{Pt}_{80} \mathrm{Ru}_{20} / \mathrm{C}$ nanowires

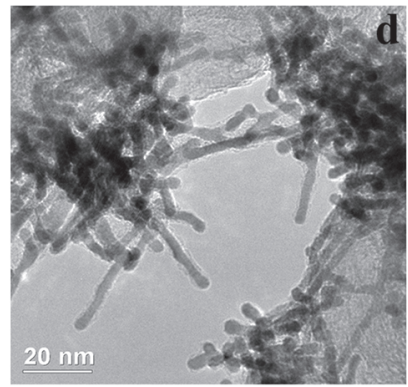

$\mathrm{Pt}_{50} \mathrm{Ru}_{50} / \mathrm{C}$ nanowires
Figure 2. TEM images of $\mathrm{Pt} / \mathrm{C}(\mathrm{a}), \mathrm{Pt}_{80} \mathrm{Ru}_{20} / \mathrm{C}(\mathrm{b}), \mathrm{Pt}_{60} \mathrm{Ru}_{40} / \mathrm{C}$ (c) and $\mathrm{Pt}_{50} \mathrm{Ru}_{50} / \mathrm{C}(\mathrm{d})$ nanowire electrocatalysts.

Figures 2(a)-(d) shows TEM images of different composition $\mathrm{Pt} / \mathrm{C}$ and $\mathrm{PtRu} / \mathrm{C}$ nanowires. Figure 2(a) shows a representative TEM image of the nanoparticles for the $\mathrm{Pt} / \mathrm{C}$ catalyst, which seem to have coalesced to form aggregates and to begin growing up of nanowires. On the other hand, in Figures 2(c)-(d) the typical thin nanowires morphology is observed. The Pt/C nanowires showed a length of $15 \mathrm{~nm} \pm$ 1.66 and a diameter of $5 \mathrm{~nm}$, while $\mathrm{Pt}_{80} \mathrm{Ru}_{20} / \mathrm{C}, \mathrm{Pt}_{60} \mathrm{Ru}_{40} / \mathrm{C}$ and $\mathrm{Pt}_{50} \mathrm{Ru}_{50} / \mathrm{C}$ have lengths and diameters of 19 and $6 \mathrm{~nm}$; $12 \mathrm{~nm}$ and $4 \mathrm{~nm} ; 18 \mathrm{~nm}$ and $4 \mathrm{~nm}$; respectively.

The surfaces of the catalysts were characterised by XPS following the $\mathrm{Pt} 4 f_{7 / 2}$ and $\mathrm{Ru} 3 p_{3 / 2}$ transitions. The Pt $4 f$ region displays a double peak produced by the spin-orbital splitting of the $4 f_{7 / 2}$ and $4 f_{5 / 2}$ states. Figure 3 (a) shows the XPS profiles for the $\mathrm{Pt}_{60} \mathrm{Ru}_{40} / \mathrm{C}$ catalyst, as a representative example, since similar behaviour occurred for all samples. The values of maximum energy appear at $71.6 \mathrm{eV}$ and $74.6 \mathrm{eV}$ for main band, suggesting that $\mathrm{Pt}$ is in the metallic state. The broad profiles were deconvoluted in four peaks with maxima at 71.5, 72.7, 74.6 and $76.0 \mathrm{eV}$ (correspond to $\mathrm{Pt} 4 f_{7 / 2}$ and $\mathrm{Pt} 4 f_{5 / 2}$ transitions of $\mathrm{Pt}$ ) related to $\mathrm{Pt}$ with different oxidation states on catalyst surface. The binding energies of $\mathrm{Pt} 4 f_{7 / 2}$ and $\mathrm{Pt} 4 f_{5 / 2}$ components localized at 72.7 and $76.0 \mathrm{eV}$ can be assigned to the $\mathrm{Pt}^{2+} .{ }^{52}$ Since the binding energy for the $3 d$ line of $\mathrm{Ru}$ in the zero-valence state $(284.3 \mathrm{eV})$ is very close to the $\mathrm{C} 1 \mathrm{~s}$ line, it is necessary to take other peak, in this case, Ru $3 p_{3 / 2}$ peak, for the determination of the oxidation states. ${ }^{53}$ One peak is obtained from ruthenium response, according to binding energies of $463.5 \mathrm{eV}$ (Fig. 3(b)), which can be assigned to the $\mathrm{Ru}^{4+}$ species, 

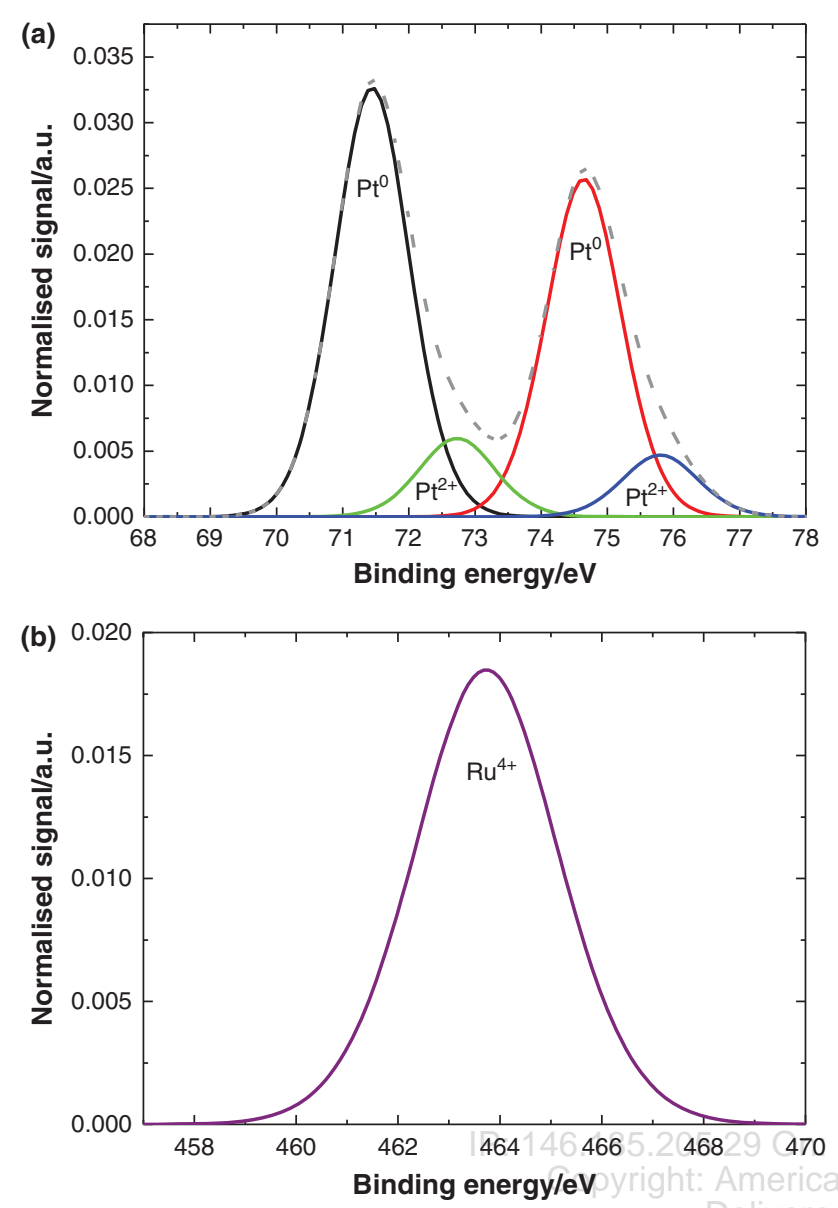

Figure 3. Pt $4 f$ (a) and Ru $3 p$ (b) transitions in XPS experiments performed with $\mathrm{Pt}_{60} \mathrm{Ru}_{40} / \mathrm{C}$ catalyst.

\subsection{Electrochemical Experiments}

Figure 4 shows the cyclic voltammograms obtained for $\mathrm{Pt} / \mathrm{C}$ and $\mathrm{PtRu} / \mathrm{C}$ nanowires in acid medium $\left(\mathrm{H}_{2} \mathrm{SO}_{4}\right)$ and in the absence of methanol. The results show the

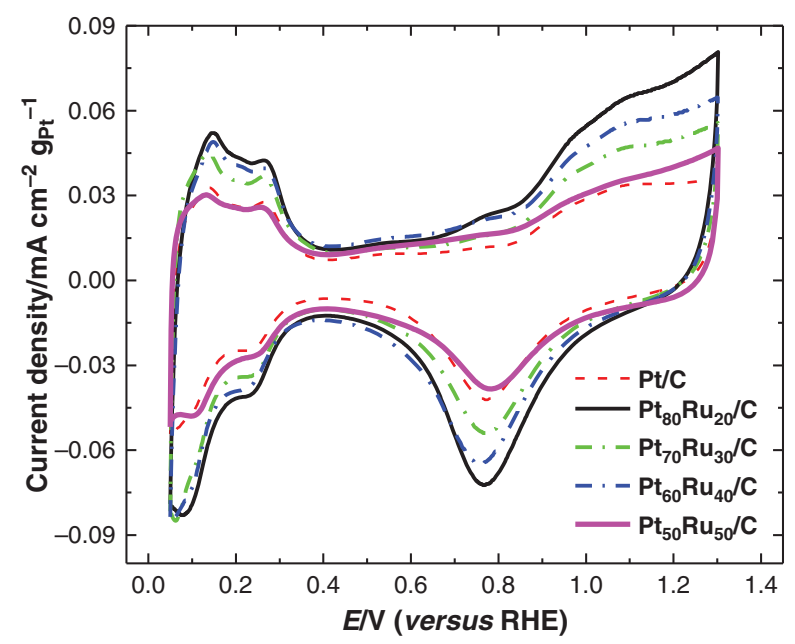

Figure 4. Cyclic voltammograms recorded on the studied eletrocatalysts taken in $0.5 \mathrm{M} \mathrm{H}_{2} \mathrm{SO}_{4}$ electrolyte. Sweep rate: $20 \mathrm{mV} \mathrm{s}^{-1}$. typical peaks corresponding to the adsorption-desorption process and the oxide regions of $\mathrm{Pt}$ on materials in acid solutions. ${ }^{54}$ The current values observed in the voltammograms for $\mathrm{PtRu} / \mathrm{C}$ catalysts are larger than those for $\mathrm{Pt} / \mathrm{C}$, which is consistent with the nanowire structure formed. The $\mathrm{Pt} / \mathrm{C}$ catalyst formed more aggregate nanowires than the $\mathrm{Pt}-\mathrm{Ru} / \mathrm{C}$ catalysts, as it demonstrated by TEM analysis. The presence of amorphous Ru-oxides increasing the electrode capacitance and therefore a large value for the double-layer charging current $(0.3-0.9 \mathrm{~V})$ is displayed for $\mathrm{PtRu} / \mathrm{C}$ nanowires. ${ }^{55}$ It can be observed that the charge in adsorption-desorption peaks and the pseudo current density increases with the amount of Pt in the nanowire catalysts, which is directly related to the quantity of available active sites. ${ }^{56}$

The electrochemical surface area of the electro-catalysts was determined by using the hydrogen desorption region observed in the cyclic voltammograms obtained in an aqueous acidic medium (Fig. 4). It was assumed that the normalised charge density for a monolayer of adsorbed hydrogen on polycrystalline platinum is $210.0 \mu \mathrm{C} \mathrm{cm}^{-2} 53$ and that all platinum loaded on the working electrode was electrochemically active. The electrochemical surface area for $\mathrm{Pt}_{80} \mathrm{Ru}_{20} / \mathrm{C}, \mathrm{Pt}_{70} \mathrm{Ru}_{30} / \mathrm{C}, \mathrm{Pt}_{60} \mathrm{Ru}_{40} / \mathrm{C}, \mathrm{Pt}_{50} \mathrm{Ru}_{50} / \mathrm{C}$ and $\mathrm{Pt} / \mathrm{C}$ nanowires was $52 \mathrm{~cm}^{2}, 49 \mathrm{~cm}^{2}, 48 \mathrm{~cm}^{2}, 41 \mathrm{~cm}^{2}$ and $33 \mathrm{~cm}^{2}$, respectively, being the largest area for $\mathrm{Pt}_{80} \mathrm{Ru}_{20} / \mathrm{C}$ nanowires. In the potential range from 0.9 to 1.30 (anodic sweep) there is an increase in the pseudo-current density as the quantity of platinum increases on the catalyst due to the amount of oxides formed during the oxidation of platinum. Consequently, an increase in the reduction peak (cathodic scan) exists due to the formation of these oxides. The process is almost reversible since there is a displacement in the peaks with increased current (anodic and cathodic).

The electro-catalytic activities of the different catalysts for the oxidation of methanol were compared by $\mathrm{CV}$, chronoamperometric and quasi-steady-state polarisation measurements at room temperature. Figure 5(a) shows the forward scans of electro-catalysts for all catalysts, showing the characteristics peaks of methanol electro-oxidation at all catalysts. The conventional voltammograms of $\mathrm{PtRu} / \mathrm{C}$ nanowires displayed the typical behaviour for methanol oxidation using Pt-base catalysts, a single oxidation peak with maximum current at $400-500 \mathrm{~mA} \cdot \mathrm{cm}^{2} \cdot \mathrm{g}_{\mathrm{Pt}}^{-1}$ during the forward scan. Other peak is observed during the backward scan (Fig. 5(b), maximum current, between 484 and $\left.820 \mathrm{~mA} \cdot \mathrm{cm}^{2} \cdot \mathrm{g}_{\mathrm{Pt}}^{-1}\right)$, which could be attributed to further oxidation of the adsorbed methanol intermediate species formed in the forward sweep process. The higher intensity in the oxidation peak during the forward sweep is related to the higher capacity to oxidize methanol and/or its intermediate products at higher potentials with more active sites free for continuous oxidation. Thus, it demonstrate that $\mathrm{PtRu} / \mathrm{C}$ nanowires had a better capacity to oxidize methanol than the nanoparticle 

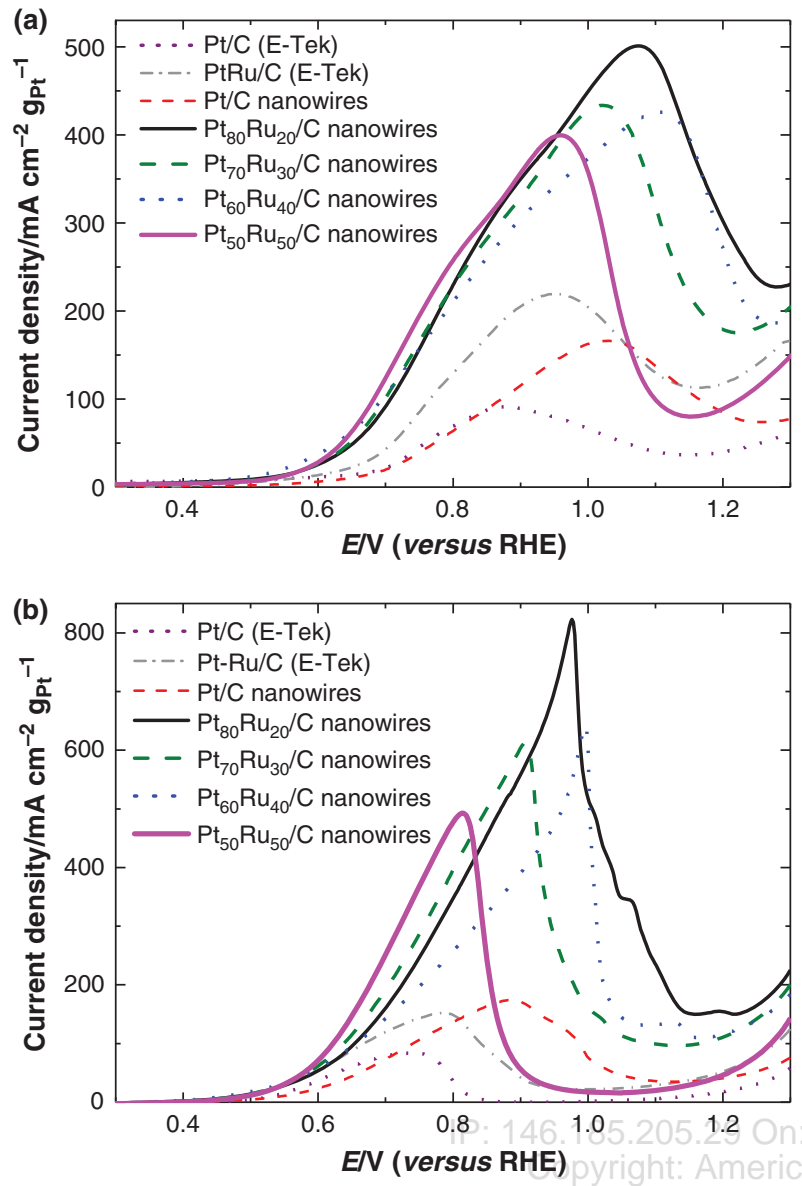

Figure 5. Cyclic voltammograms recorded for the oxidation of methanol on the developed electrocatalysts in $0.50 \mathrm{M} \mathrm{CH}_{3} \mathrm{OH}+0.5 \mathrm{M}$ $\mathrm{H}_{2} \mathrm{SO}_{4}$ solution. Sweep rate: $20 \mathrm{mV} \mathrm{s}^{-1}$. (a) Anodic forward sweep and (b) backward sweep.

catalysts, Pt/C and PtRu/C from E-Tek (commercial catalysts).

At low overpotentials, the profiles show similar electrocatalytic activity for all catalysts, although the $\mathrm{Pt}_{60} \mathrm{Ru}_{40} / \mathrm{C}$ catalyst shows a better performance. The addition of ruthenium to $\mathrm{Pt} / \mathrm{C}$ decreases the onset potential of methanol electro-oxidation by about $0.12 \mathrm{~V}$ and $0.15 \mathrm{~V}$ related to $\mathrm{Pt} / \mathrm{C}$ from $\mathrm{E}-\mathrm{Tek}$ and $\mathrm{Pt} / \mathrm{C}$ nanowire, respectively. The energy necessary for methanol electro-oxidation is lower, which could be attributed to both the synergetic role of ruthenium in platinum catalytic activity for methanol electro-oxidation ${ }^{11}$ and the structural modification of Pt by Ru. ${ }^{57}$ Figure 6 show the chronoamperometric curve recorded at $0.6 \mathrm{~V}$ versus $\mathrm{RHE}$ for methanol electro-oxidation of $\mathrm{Pt}_{80} \mathrm{Ru}_{20} / \mathrm{C}, \mathrm{Pt}_{70} \mathrm{Ru}_{30} / \mathrm{C}, \mathrm{Pt}_{60} \mathrm{Ru}_{40} / \mathrm{C}$, $\mathrm{Pt}_{50} \mathrm{Ru}_{50} / \mathrm{C}$ and $\mathrm{Pt} / \mathrm{C}$ nanowires as well as the results for $\mathrm{Pt} / \mathrm{C}$ and PtRu/C (both E-Tek) catalysts used as reference materials. During the first seconds, there is a sharp decrease in the current density followed by a slow decrease in the current values over longer periods. A relatively steady-state behaviour ocurr for all studied catalysts after ca. $100 \mathrm{~s}$. This behaviour is related to poisoning by

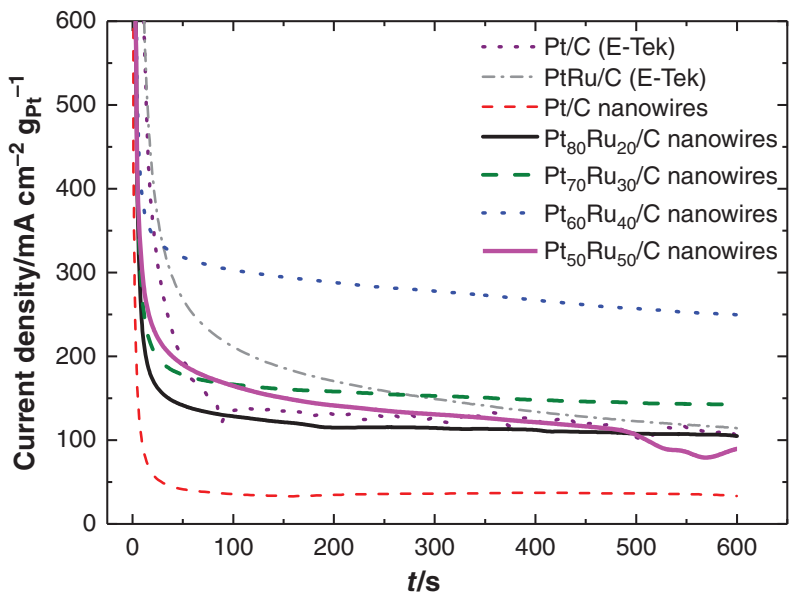

Figure 6. Chronoamperometric measurements of methanol oxidation at $0.6 \mathrm{~V}$ versus $\mathrm{RHE}$ on the developed electrocatalysts in $0.50 \mathrm{CH}_{3} \mathrm{OH}+$ $0.5 \mathrm{M} \mathrm{H}_{2} \mathrm{SO}_{4}$ solution.

intermediate products from methanol electro-oxidation. ${ }^{58}$ After $600 \mathrm{~s}$, the $\mathrm{Pt}_{60} \mathrm{Ru}_{40} / \mathrm{C}$ nanowire displayed a value of pseudo-current density three times greater than those for the commercial catalytic composite.

Figure 7 shows the anode polarisation curves. The onset potential of methanol electro-oxidation over $\mathrm{Pt}_{60} \mathrm{Ru}_{40} / \mathrm{C}$ shifted about $0.2 \mathrm{~V}$ negatively in comparison with the other PtRu nanowires. The onset potential for the PtRu/C (E-Tek) nanocatalyst used as the reference is the same, but the current density decreases with potential. $\mathrm{Pt}_{60} \mathrm{Ru}_{40} / \mathrm{C}$ and $\mathrm{Pt}_{80} \mathrm{Ru}_{20} / \mathrm{C}$ catalysts showed the highest values with increased potential. From these results, the catalyst with the best behaviour in the test conditions was $\mathrm{Pt}_{60} \mathrm{Ru}_{40} / \mathrm{C}$ nanowires.

The durability of $\mathrm{PtRu} / \mathrm{C}$ nanowires is another important variable that affects the implementation of this system at the commercial level. PtRu/C catalysts are normally

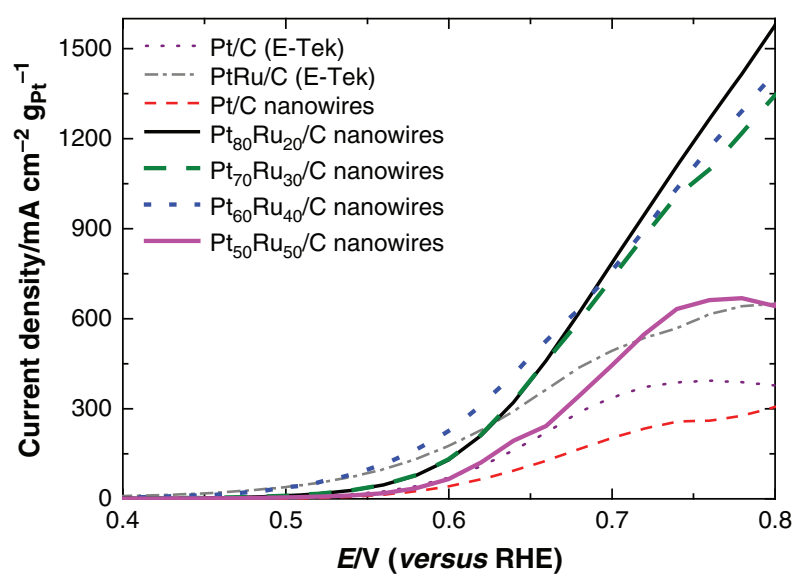

Figure 7. Quasi-steady-state anode polarisation profiles for the oxidation of methanol in $0.50 \mathrm{M} \mathrm{CH}_{3} \mathrm{OH}+0.5 \mathrm{M} \mathrm{H}_{2} \mathrm{SO}_{4}$ solution. All data were obtained from the potentiostatic values measured after $300 \mathrm{~s}$ of polarization. 

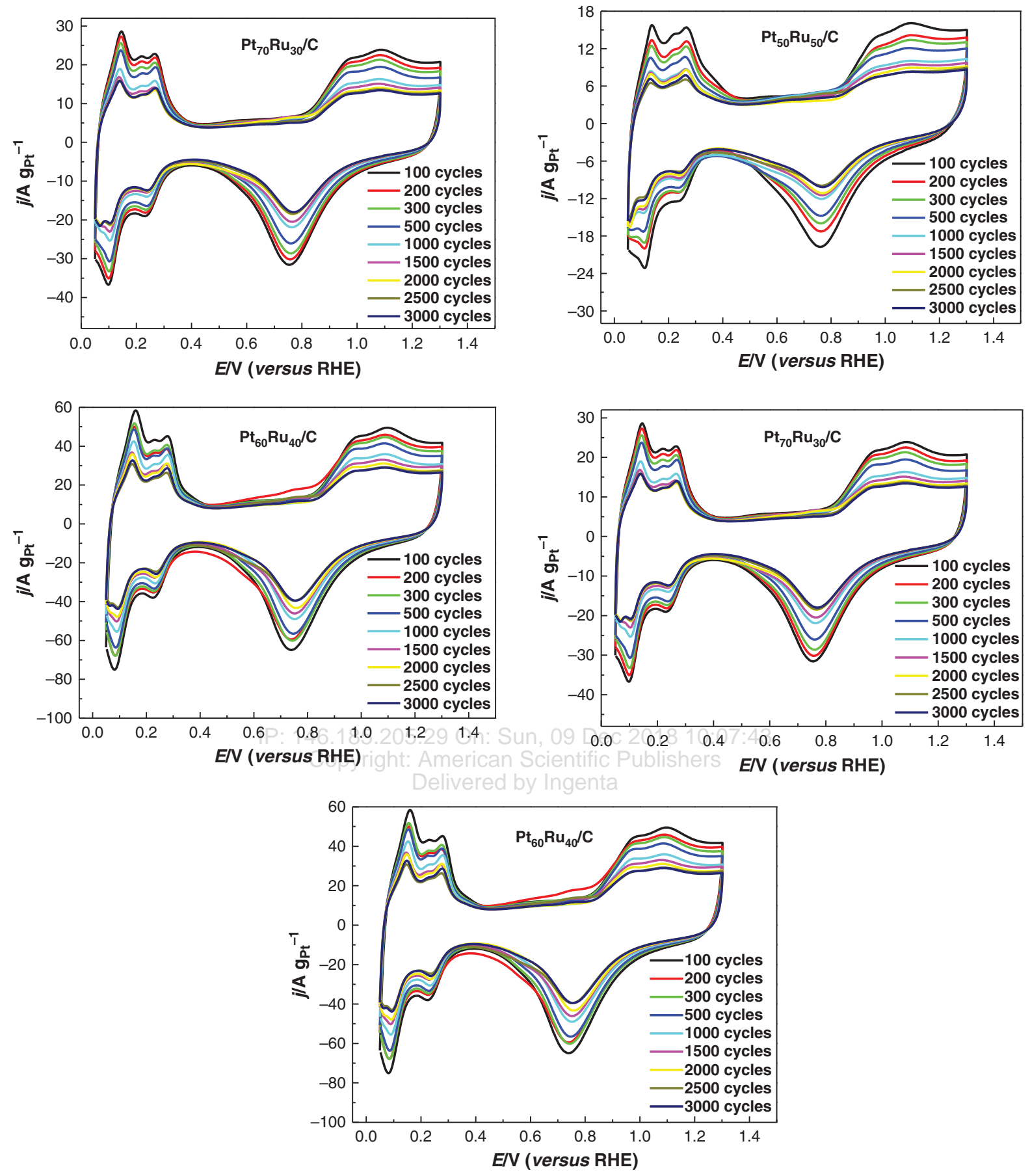

Figure 8. Stability test for electrocatalysts in $0.5 \mathrm{M} \mathrm{H}_{2} \mathrm{SO}_{4}$ electrolyte. Sweep rate: $20 \mathrm{mV} \mathrm{s}^{-1}$.

employed as the highly active anode electro-catalyst, but it undergoes dissolution and particle aggregation under fuel cell conditions. ${ }^{59}$ The stability of the anode electrocatalyst synthesised by the chemical reduction method was evaluated by cycling the electrode potential between 0.05 and $1.30 \mathrm{~V}$ versus RHE for 3000 cycles following a procedure already reported to test the stability of carbon-supported nanocatalysts. ${ }^{60}$ Figure 8 shows the CVs of the PtRu/C nanowires after an increasing number of potential cycles until 1000 cycles. The electrochemical surface area (hydrogen desorption area in the $\mathrm{Pt}-\mathrm{H}$ oxidation region) decreases after this test, indicating the instability of the active species. The electrochemical surface area lost after 3000 cycles was $25 \%$ for $\mathrm{Pt}_{60} \mathrm{Ru}_{40} / \mathrm{C}$, while for $\mathrm{Pt} / \mathrm{C}, \mathrm{Pt}_{80} \mathrm{Ru}_{20} / \mathrm{C}, \mathrm{Pt}_{70} \mathrm{Ru}_{30} / \mathrm{C}$ and $\mathrm{Pt}_{50} \mathrm{Ru}_{50} / \mathrm{C}$ nanowires were $45 \%, 42 \%, 43 \%$, and $55 \%$, respectively. Thus, the $\mathrm{Pt}_{60} \mathrm{Ru}_{40} / \mathrm{C}$ nanowires were the most stable of the tested catalysts. 


\subsection{Mechanistic Insights}

Application of derivative voltammetry to the results obtained for cyclic voltammetry allows a better understanding of methanol electro-oxidation. Figure 9 show derivative voltrammograms obtained from forward scans of the electro-catalysts, in which the characteristic peaks of methanol electro-oxidation are observed. ${ }^{61}$ Derivative voltammograms display negative and positive peaks. If this representation is compared with the corresponding conventional voltammograms is possible to see that weak shoulders that are not detectable in the convectional voltammograms. For instance, in the derivative voltammograms of methanol oxidation the electro-catalysts show a shoulder around $0.7 \mathrm{~V}$, which is rarely visible in the conventional voltammogram (Fig. 5(a)), while it is well resolved into a peak in the derivative voltammogram (Fig. 9(a)). Murthy et al. ${ }^{61}$ studied the methanol oxidation by means of voltammetric conditions and proposed a mechanistic insight through derivative voltammograms. Taking analogous considerations into account a similar analysis was performed for the $\mathrm{PtRu} / \mathrm{C}$ nanowires (Fig. 9(b)). From this results, we can establish that the
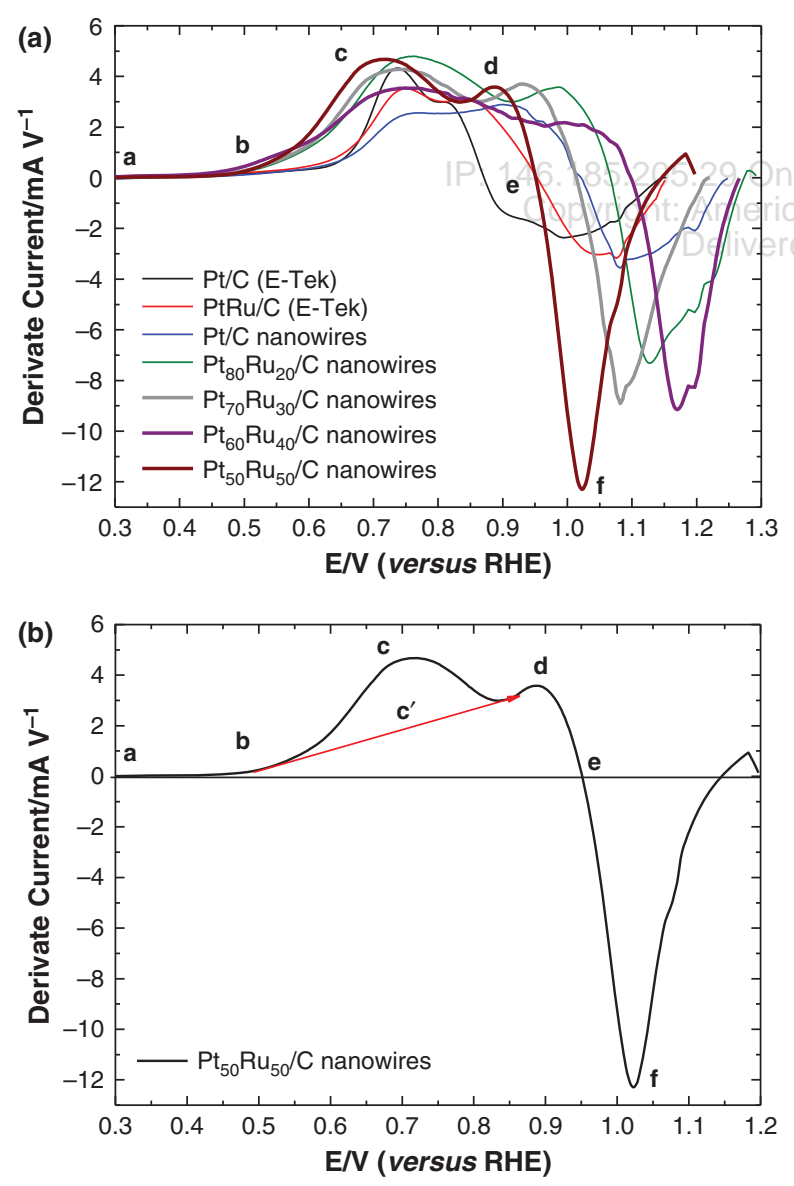

Figure 9. (a) Derivative voltammograms for the oxidation of methanol on synthesised electrocatalysts carried out in $0.50 \mathrm{M} \mathrm{CH}_{3} \mathrm{OH}+0.5 \mathrm{M}$ $\mathrm{H}_{2} \mathrm{SO}_{4}$ solution. (b) Derivative voltammetry for $\mathrm{Pt}_{50} \mathrm{Ru}_{50} / \mathrm{C}$ nanowire electrocatalytic composite. Sweep rate: $20 \mathrm{mV} \mathrm{s}^{-1}$. electro-oxidation of methanol on $\mathrm{PtRu} / \mathrm{C}$ nanowires synthesised and tested in this work occurs through a serial path mechanism with similar elementary reaction steps as those present in the oxidation of one carbon molecules like methanol, formic acid or formaldehyde. ${ }^{63}$ The mechanistic insight gained through the derivative voltammogram for $\mathrm{Pt}_{50} \mathrm{Ru}_{50} / \mathrm{C}$ nanowires is illustrated in Figure 9(b), the analysis is based on proposed mechanistic insights by Murthy et al. ${ }^{61}$

Point a: Dissociative adsorption, hydrogen atoms removal and $\mathrm{CO}$ coverage of $\mathrm{Pt}$ active surface sites.

Point b: The rate-determining step (methanol dehydrogenation).

Point c: Methanol oxidation through a parallel path.

Point $\mathrm{c}^{\prime}$ : Oxidation of $\mathrm{CO}$ to $\mathrm{CO}_{2}$.

Point d: Methanol oxidation by generation of $\mathrm{OH}$ on Pt sites.

Point e: Voltammetric current reaches a maximum and then begins decreasing.

Point $\mathrm{f}$ : The active sites of the catalyst are covered by $\mathrm{OH}_{\mathrm{ad}}$.

In addition, the onset potential for methanol electrooxidation (point (b) in Fig. 9), is shifted to lower potentials at the binary developed nanowire electro-catalysts related to Pt nanowires and both commercial catalysts.

\section{CONCLUSIONS}

$\mathrm{A}$ series of $\mathrm{PtRu} / \mathrm{C}$ nanowires with different composition of $\mathrm{Pt}$ and $\mathrm{Ru}$ were prepared and used as anodes in the electro-oxidation of methanol in acid media. The $\mathrm{Pt}_{60} \mathrm{Ru}_{40} / \mathrm{C}$ catalyst showed the best behaviour in the tested conditions, negatively shifting the onset potential of methanol electro-oxidation by about $0.2 \mathrm{~V}$ in comparison with the other $\mathrm{PtRu} / \mathrm{C}$ nanowires prepared. The energy necessary for methanol electro-oxidation is attributable to both the synergetic role of ruthenium with platinum and the structural modification of $\mathrm{Pt}$ by $\mathrm{Ru}$. The electro-oxidation of methanol on $\mathrm{PtRu} / \mathrm{C}$ nanowires occurs through a serial path mechanism with similar elementary reaction steps to those presented by oxidation of one carbon molecule. Although the amount of noble metal $(\mathrm{Pt})$ decreased, the next step to optimize the catalyst composition will be to decrease the metal loading from $40 \%$ (w/w) to lower values.

Acknowledgments: The authors thank to $\mathrm{CNPq}$ (grants: 304419/2015-0, 402243/2012-9, 400443/2013-9, 407274/2013-8 and 310282/2013-6), CAPES and FAPITEC for the scholarships and financial support.

\section{References and Notes}

1. Z.-B. Wang, G.-P. Yin, Y.-Y. Shao, B.-Q. Yang, P.-F. Shi, and P.-X. Feng, J. Power Sources 165, 9 (2007).

2. J. O. M. Bockris, S. U. M. Khan, Surface Electrochemistry, Plenum Press, New York (1993). 
3. C. Lamy, A. Lima, V. Lerhun, F. Delime, C. Coutanceau, and J. Léger, J. Power Sources 105, 283 (2002).

4. T. Iwasita, Electrochim. Acta 47, 3663 (2002).

5. A. Hamnett, Catal. Today 38, 445 (1997).

6. T. Yajima, H. Uchida, and M. Watanabe, J. Phys. Chem. B 108, 2654 (2004).

7. Y. Ishikawa, M.-S Liao, and C. R. Cabrera, Surf. Sci. 463, 66 (2000).

8. S. L. Gojkovic, T. R. Vidakovic, and D. R. Durovic, Electrochim. Acta 48, 3607 (2003).

9. A. S. Arico, P. L. Antonucci, E. Modica, V. Baglio, H. Kim, and V. Antonucci, Electrochim. Acta 47, 3723 (2002).

10. J. S. Spendelow, P. K. Babu, and A. Wieckowski, Curr. Opin. Solid STM 9, 37 (2005).

11. M. Watanabe and S. Motoo, J. Electroanal. Chem. 60, 267 (1975).

12. E. I. Santiago, V. A. Paganin, M. Carmo, E. R. Gonzalez, and E. A. Ticianelli, J. Electroanal. Chem. 575, 53 (2005).

13. K. W. Park, J. H. Choi, S. A. Lee, C. Pak, H. Chang, and Y. E. Sung, J. Catal. 224, 236 (2004).

14. H. A. Gasteiger, N. Markovic, P. N. Ross, and E. J. Cairns, J. Electrochem. Soc. 141, 1795 (1994).

15. K.-W. Park, J.-H. Choi, B.-K. Kwon, S.-A. Lee, Y.-E. Sung, H.-Y. Ha, S.-A. Hong, H. Kim, and A. Wieckwski, J. Phys. Chem. B 106, 1869 (2002).

16. Y.-L. Yao, Y. Ding, L.-S. Ye, and X.-H. Xia, Carbon 44, 61 (2006).

17. M. E. Tess, P. L. Hill, K. E. Torraca, M. E. Kerr, K. A. Abboud, and L. McElwee-White, Inorg. Chem. 39, 3942 (2000).

18. Z. He, J. Chen, D. Liu, H. Zhou, and Y. Kuang, Diam. Relat. Mater. 13, 1764 (2004).

19. D. Chu and R. Jiang, Solid State Ionics 148, 591 (2002).

20. J. W. Guo, T. S. Zhao, J. Prabhuram, R. Chen, and C. W. Wong, Electrochim. Acta 51, 754 (2005).

21. S. Shironita, K. Karasuda, K. Sato, and M. Umeda, J. Power Sources 240, 404 (2013).

22. J. Jiang and A. Kucernak, J. Electroanal. Chem. 543, 187 (2003).

23. Y. E. Seidel, A. Schneider, Z. Jusys, B. Wickman, B. Kasemo, and R. J. Behm, Langmuir 26, 3569 (2010).

24. C.-H. Chen, L. S. Sarma, D.-Y. Wang, F.-J. Lai, C.-C. Al Andra, S.-H. Chang, D.-G. Liu, C.-C. Chen, J.-F. Lee, and B.-J. Hwang, Chemcatchem. 2, 159 (2010).

25. C. Yang, D. Wang, X. Hu, C. Dai, and L. Zhang, J. Alloy. Compd. 448, 109 (2008).

26. S. J. Yoo, T. Y. Jeon, Y.-H. Cho, K.-S. Lee, and Y.-E. Sung, Electrochim. Acta 55, 7939 (2010).

27. A. B. Kashyout, A. B. A. A. Nassr, L. Giorgi, T. Maiyalagan, and B. A. B. Youssef, Int. J. Electrochem. Sci. 6, 379 (2011).

28. Y.-C. Liu, X.-P. Qiu, Y.-Q. Huang, W.-T. Zhu, and G.-S. Wu, J. Appl. Electrochem. 32, 1279 (2002).

29. O. Sahin and H. Kivrak, Int. J. Hydrogen Energ. 38, 901 (2013).

30. S. Song, Y. Liang, Z. Li, Y. Wang, R. Fu, and D. Wu, Appl. Catal. B-Environ. 98, 132 (2010).

31. M. Arenz, K. J. J. Mayrhofer, V. Stamenkovic, B. B. Blizanac, T. Tomoyuki, P. N. Ross, and N. M. Markovic, J. Am. Chem. Soc. 127, 6819 (2005)

32. N. Tian, Z.-Y. Zhou, S.-G. Sun, Y. Ding, and Z. L. Wang, Science 316, 732 (2007).

33. J. X. Wang, H. Inada, L. Wu, Y. Zhu, Y. Choi, P. Liu, W.-P. Zhou, and R. R. Adzic, J. Am. Chem. Soc. 131, 17298 (2009).

34. B. Lim, T. Yu, and Y. Xia, Angew. Chem. Int. Ed. 49, 9819 (2010).

35. W. Zhou, M. Li, C. Koenigsmann, C. Ma, S. S. Wong, and R. R. Adzic, Electrochim. Acta. 56, 9824 (2011).
36. C. Koenigsmann, W.-P. Zhou, R. R. Adzic, E. Sutter, and S. S. Wong, Nano Lett. 10, 2806 (2010)

37. C. Koenigsmann and S. S. Wong, Energy Environ. Sci. 4, 1161 (2011).

38. S. Sun, F. Jaouen, and J.-P. Dodelet, Adv. Mater. 20, 3900 (2008).

39. H. Zhou, W.-P. Zhou, R. R. Adzic, and S. S. Wong, J. Phys. Chem. C 113, 5460 (2009).

40. S. Wang, S. P. Jiang, X. Wang, and J. Guo, Electrochim. Acta 56, 1563 (2011).

41. J. C. M. Silva, R. F. B. Souza, L. S. Parreir, E. T. Neto, M. L. Calegaro, and M. C. Santos, Appl. Catal. B-Environ. 99, 265 (2010).

42. E. Christoffersen, P. Liu, A. Ruban, H. L. Skriver, and J. K. Norskov, J. Catal. 199, 123 (2001).

43. S. Sun, G. Zhang, D. Geng, Y. Chen, R. Li, M. Cai, and X. Sun, Angew. Chem. Int. Ed. 50, 422 (2011).

44. B. Li, D. C. Higgins, S. Zhu, H. Li, H. Wang, J. Ma, and Z. Chen, Catal. Commun. 18, 51 (2012).

45. F. E. López-Suárez, M. Perez-Cadenas, A. Bueno-López, C. T. Carvalho-Filho, K. I. B. Eguiluz, and G. R. Salazar-Banda, J. Appl. Electrochem. 45, 1057 (2015).

46. G. R. Salazar-Banda, K. I. B. Eguiluz, M. M. S. Pupo, H. B. Suffredini, M. L. Calegaro, and L. A. Avaca, J. Electroanal. Chem. 668, 13 (2012).

47. F. E. López-Suárez, C. T. Carvalho-Filho, A. Bueno-López, J. Arboleda, A. Echavarría, K. I. B. Eguiluz, and G. R. SalazarBanda, Int. J. Hydrogen Energ. 40, 12674 (2015).

48. S. H. Sun, D. Q. Yang, G. X. Zhang, E. Sacher, and J. P. Dodelet, Chem. Mater. 19, 6376 (2007).

49. Joint Committee on Powder Diffraction Standards-(JCPDS card: 04-802).

50. P. Sivakumar and V. Tricoli, Electrochem. Solid ST 9, A167 (2006). 2018 10:07:43

51. C.f D. Wagner, L. E. Davis, M. V. Zeller, J. A. Taylor, R. H. Raymond, and L. H. Gale, Surf. Interface Anal. 3, 211 (1981).

52. S. Sun, D. Yang, D. Villers, G. Zhang, E. Sacher, and J.-P. Dodelet, Adv. Mater. 20, 571 (2008).

53. W. Vielstich, A. Lamm, and H. A. Gasteiger, Handbook of Fuel Cells, John Wiley \& Sons, England (2003).

54. A. J. Dean (ed.), Lange's Handbook of Chemistry, 13th edn., McGraw-Hill, New York (1985).

55. H. Angerstein-Kozlowska, B. E. Conway, and B. A. Sharp, J. Electroanal. Chem. 43, 9 (1973).

56. M. Brandalise, R. W. R. Verjulio-Silva, M. M. Tusi, O. V. Correa, L. A. Farias, M. Linardi, E. V. Spinacé, and A. O. Neto, Ionics (Kiel) 15, 743 (2005).

57. W. S. Li, L. P. Tian, Q. M. Huang, H. Li, H. Y. Chen, and X. P. Lian, J. Power Sources 104, 281 (2002).

58. E. S. Steigerwalt, G. A. Deluga, and C. M. Lukehart, J. Phys. Chem. B 106, 760 (2002).

59. A. Taniguchi, T. Akita, K. Yasuda, and Y. Miyazaki, J. Power Sources 130, 42 (2004).

60. D. Wang, H. L. Xin, Y. Yu, H. Wang, E. Rus, D. A. Muller, and H. D. Abruña, J. Am. Chem. Soc. 132, 17664 (2010).

61. A. Murthy and A. Manthiram, J. Phys. Chem. C 116, 3827 (2012).

62. H. Okamoto, W. Kon, and Y. Mukouyama, J. Phys. Chem. B 109, 15659 (2005).

63. H. S. Nalwa (ed.), Encyclopedia of Nanoscience and Nanotechnology, American Scientific Publishers, Los Angeles, CA (2004), Vols. 1-10.

Received: 5 October 2017. Accepted: 9 February 2018. 